\title{
Designrama
}

\section{Design in Egypt.}

A Historic and Theoretical Context

\section{Qassim Saad}

Curtin University

qassim.saad@curtin.edu.au

ORCID 0000-0002-5641-9957

\section{Abstract}

This study is observing design in Egypt to articulate its theoretical framework, which developed since the establishments of the early model of vocational school in 1839. The school formed to provide much needed skilled workers for the modern industrial productions capabilities progressively established at that time. The school transformed during the postcolonial era to take the current educational institution of applied arts. Building on Egypt's geopolitical superiority and cultural influences in the region, its design education model spread across many neighbouring countries. Egypt is one of the ancient centres of skilled craftsmanship, traditional crafts as socio-cultural context and practices continue to influence the applied arts teaching pedagogy. The study argues the need to consider the role of design in the social context and move it outside its traditional context and practices of making and ornamenting material objects.
\end{abstract}

\section{Keywords}

Design in Egypt

Post-colonisation

Modernisation

Applied arts

Crafts 


\section{Modernisation: The Post-colonisation Context}

The Eastern Mediterranean Region (EMR) includes Egypt, Palestine, Jordan, Lebanon, Syria, and Iraq, characterised by rich yet diverse history, but also imposed rules by foreign power to military occupation. In this region, a new era replaced the era of European colonialism that dominated the world prior to the First and the Second World Wars. It was shaped, according to Mignolo (2011, p. 32), "not by appropriating land, but by managing finances and natural resources through the project of development and modernization". The new era gradually enhanced applying the progenitor knowledge, "epistemological colonialism can be understood as a certain kind of viral afterlife of a progenitor; it goes on doing the job of colonisation long after the material trappings of its parental host have departed" (Fry \& Eleni, 2014, p. 4). Considering that during the new era beginning in the mid-20th century, the terms "development" and "modernisation" shared equal meaning in political, economic and social rhetoric, specifically in relation to the nature of these terms. Mignolo (2011, p. 47) affirmed that "Modernization means that you want to have a comfortable, middle-class existence with all the amenities and attributes that go along with it - clean water, indoor plumbing, electricity, telecommunications, infrastructure, personal safety, rule of law, stable politics and a good education system". Modernity, according to Fry (2011, p. 221), "emerged from independent philosophic, scientific, cultural, political and economic projects initiated in different times and places". However, the crises of modernity in many developing nations, promoted - politically and socially — the transformation toward Westernisation, as way of living. The modernity endorsed over traditional cultural practices is reflected through "de-traditionalisation" in many of these conservative societies.

Political reform, in some of these regional nations, rejected colonialism yet considered modernity. An example of this is Egypt's military coup in 1952 and the establishment of a military-oriented socialist republic in the former liberal kingdom. This dual vision between Westernism and coloniality dominated the socio-political rhetoric in the region and was reflected in politics, economics as well as social and cultural practices (Al-Musawi, 2006). The socio-political reform represented a hegemony of nationalist elites since 1960s, it "become genuinely popular, so it has come less national and more religious - in other words less Arab and more Islamic" (Said, 1979, p. 317) and promoted development and modernisation to defeat the legacy of colonialism. Especially in Egypt, this elite "eventually embraced forms of Arab Socialism, which was supposed to produce modernism in a fashion consistent with Arab customs and traditions" (Lee, 1997, p. 7). Gradually, the principle of authenticity emerged to make modernisation a representation of Western phenomena consisting exclusively of a choice between East or West, traditional or modern. In fact, modernity was heavily criticised as relating to "uniformity, impersonality, superficiality, commercialism, self-interested individualism, and infatuation with technology" (Lee, 1997, p. 13).

The contradiction between the characteristics of modernity and the conservative and religious nature of the regional societies continues to be one of the major topics within socio-cultural studies (Radhakrishnan, 2012). The decades after the 1950s, when there 
were movements to create national republican states in Egypt, and later in Iraq and Syria. These movements resulted in military coups that created nationalist and socialist governments which supported development and modernisation strategies from the 1960s onward. The relative political and social stability that occurred in Egypt from the 1950s was supported by demographic and cultural superiorities. These factors were associated with promoting the progression towards modernisation, which was reflected in wider demographic changes such as population growth, especially in the major cities of Cairo, Alexandria and others. The socialist policies introduced during those decades enhanced the position of the government in leading the economy. At the same time, they were reflected in infrastructure development - mainly in the major cities - , public and private architecture, public transportation, education, health services and media. These achievements compared Egypt with developing countries. Additionally, there was radical transformation in the very restrictive nature of Egyptian society, as seen in several cultural aspects such as literature, poetry, fiction, art, sport, media, theatre and cinema. An example is the film industry: Egypt has been known as the "Hollywood" for Arabic language movies since the early 1900 s (Hourani, 2005).

Benefiting from its population size, the Egyptian workforce applied effective support to the newly established nation states in the region, providing both technical and craftsmanship workers in the fields of education, health services, infrastructure and social services. In higher education, many Arabic universities relied on Egyptian academics to support their institutions and deliver academic programs, choosing teaching language of Arabic, shared by all the Middle East and North African Region (MENA) countries. The majority of design education programs in MENA's higher education institutions were established and led by Egyptian academics. They transformed the Egyptian model of "applied arts" in many design disciplines, such as industrial design, graphic design, to name some, and applied its teaching curriculum to these institutions. For example, the current design program in Iraq was established in the early 1970 s and leads by the Egyptian industrial designer, Professor Mousad Al Kady (Saad, 2013).

\section{Emergence of Applied Arts Education in Egypt}

Studies of the contemporary discourse of design in Egypt and the region are rare, with extremely limited information on its context and practices (Saad, 2020). The limited numbers of local publications (the majority in Arabic language) were overwhelmed with the presentation of design knowledge and practices aligned with traditional local culture and social norms. Design is intensely dependent on artistic foundations and know-how concerning artisan skills and "their benefit in adding value to man-made objects through surface ornamentation" (Chadirji, 1995, p. 178). Overall, the regional societies, being conservative and religiously-oriented, still harbour nostalgia for the artistic past, in which man-made objects ornamented with symbols hold unlimited meaning. 
There are clear examples in Islamic art, where both Arabic letters and ornamental compositions (geometric and organic) typically grace architecture and crafts and contain the power of divine symbolism in addition to aesthetic values Fig. 1. This spiritual belief is based on the core position of the Arabic language in the life of Muslims, who hold that the Quran miraculously utilises language to present a precise description of religious truth: the "Arabic language had spread and became the medium of culture which incorporated elements from the traditions of peoples absorbed into the Muslim world, and expressed itself in literature and in systems of law, theology, and spirituality" (Hourani, 2005, p. 5). There is, therefore, a strong societal inclination to present this discourse as an authentic context for applied art practices. This environment encourages what Baudrillard (2002, p. 76) calls the "nostalgia for origins and the obsession with authenticity".

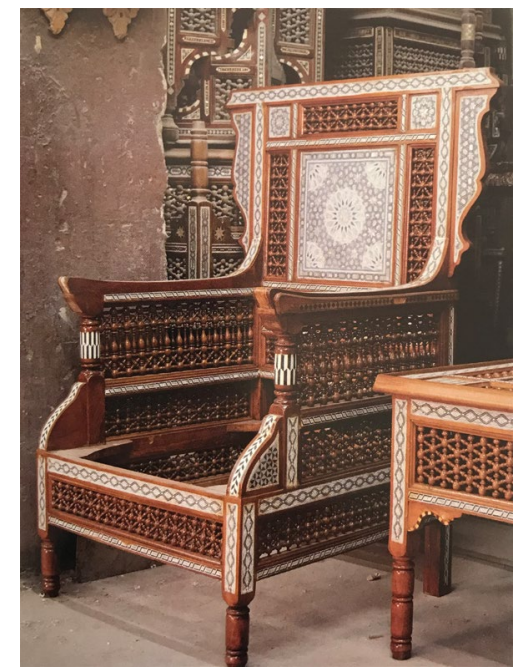

The roots of modern Egyptian cultural practices are clearly influenced by Europeans, from the early French invasion of Egypt (1798-1801), through to British colonialism (1882-1956). The project of 'Nahdah' the 'arising' "emerged from earlier European ideas of linguistic-ethnic-territorial nationalism" (Mackintosh, 2019, p. 10). The broad disagreement facing this socialist thinking in trying to balance these two phenomena is sustained by various influences and fuelled by extremists of both East and West. In his theoretical frameworks, the Egyptian thinker Mohammad Adbuh (1849-1905) addressed the distinction between presenting essential Islamic doctrines and Islamic social teaching and law. The distinction is based on the conclusion that "The doctrines have been transmitted by a central line of thinkers, the 'pious ancestors' [...] and they can be articulated and defended by reason" (Hourani, 2005, p. 308). The hegemony of certain Islamic doctrines in Arabic and Islamic countries in the current era, and its wider application in relation to open channels for mass communication, require people to believe in certain practices just because they were original Islamic practices (Cannadine, 2001).
Fig. 1

Arabesque style chair inlayed with mother of pearl, "Ali Hamama's workshop, al-Muqatam", Cairo (Al-Fakharani, 2016, p. 169). 
These practices keep expanding to cover tiny details of human interaction, as well as reflecting on objects, their social and cultural meanings, and how they are utilised for specific tasks.

These dynamic influences show how Egypt is a nation shaped by the region's rich history, where civilisations have intersected to create a unique mixture of cultures. Therefore, ornamental arts have long and rich traditions that draw influence and inspiration from Egypt's eclectic past. Building on this, Egypt offered a sustained incubator for rich and ancient traditions of craftsmanship, and skilled artisans, in the 1670s "Cairo already possessed a remarkable number of guilds: among the multitude of artisan groups (taife) recorded by Evliya Celebi, 262 units have been identified as associations encompassing the traders and artisans of Cairo proper, excluding those of Bulaq and other satellite towns" (Faroqhi, 2012, p. 129). This foundation welcomed and offered support to the "modern" concept of applied arts introduced in the early 20th century and was represented by vocational education institutions established in Cairo at that time. Craftsman practices associated with social preferences highly influenced the teaching methods and content of applied arts. This resulted in content being overloaded with artist and craftsman teaching methods and concepts. It was deeply engaged with construction under supervision, following the master as a source of knowledge and skilled coach. Therefore, applied arts education transformed into higher education with arts and crafts oriented curricula delivering a number of programs based on the making of materials, production skills and technology ${ }^{1}$. Applied arts graduates, known locally as "applied artists", were capable of maintaining traditional artisan heritage, as well as utilising new technologies to make and produce ornamented craft objects for local preferences and tourist attraction.

Although applied arts study programs in Egypt were positioned as a pioneering model that could be replicated throughout the region, none of the programs established outside Egypt after 1970 s, identified with or used the terminology of applied arts. Instead, these programs used the term "design" in their titles as a cultural statement. The similarity between the regional design schools and Egyptian applied arts institutions was related to the context and practices of art and craft identified in the curricula and subject learning outcomes. This is understandable, since the majority of those design schools were established following the Egyptian applied arts model and because of the high proportion of Egyptian academic staff at the majority of these schools.

One of the main categories traditional Egyptian applied arts graduates are pigeonholed into is that of an "artistic craftsman". Such craftsmen are qualified in imitating existing art work under the supervision of a master. They have little skill in creating innovative, economic and viable designs. This reality forces many corporations to rely on foreign designers, assign engineers to do the designer's job, or to follow the customer's preferences. Overall, local industrial production in Egypt involves a variety of industrial sectors that produce locally affordable, low-quality products targeting low-income customers. These industrial sectors are classified as "small" - to micro-sized craft-oriented family businesses, representing the major source of income for a wide range of working

\section{1}

The fi st vocational school was established in Cairo in 1839. In 1909, the school created a new study program focused on crafts and arts, which supported the development of artisan practices. In 1932, the School of Vocational Education changed its name to The School of Arts. Then, in 1942 , it was called the Higher School of Applied Arts. The school linked with the University of Helwan (state-funded university) in 1975 and became the Faculty of Applied Arts, now known as the "mother of all applied arts faculties" in Egypt. 
social classes in Egypt -; "medium" - to large state-owned and operated engineering and manufacturing corporations that operate mainly with assembly licences from international companies to produce electric home appliances and automobiles, or carry out engineering and construction projects -

In the reality of today's open markets, current industrial production in Egypt does not show evidences to compete against imported products in terms of price and quality. Even with the fact of the harsh economic situation in Egypt associating with the local economy reformed after the decline of the tourism industry, which was a major source of foreign currency. This situation opened new opportunities for local manufacturing corporations and encouraged them to rethink their product development. There was strong demand from many private sector industrial corporations for design services to support the production of more innovative local products. Their aims were to shift the standards of quality and establish a competitive position in the local market, as well as in regional ones. Such example of the Egyptian well-known furniture industry Fig. 2.

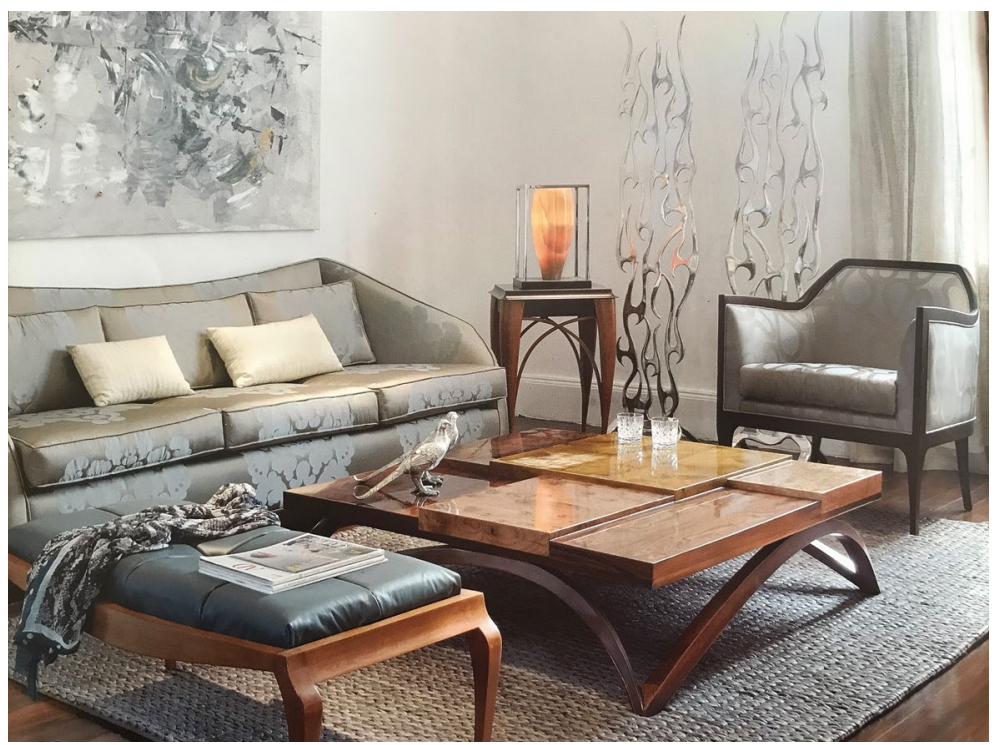

Fig. 2 Al Cazar fine oods, Egyptian modern furniture design and production, Cairo, 2015.

The Status Quo of Applied Arts in Egypt

The Faculty of Applied Arts (FAA) is the pioneering applied arts higher education institution in Egypt, as well as in the region. The FAA was transformed from trade technical school into an academic faculty to accommodate a modern institution teaching arts and crafts in Egypt. It also promotes itself as the model design institution in the region. The FAA currently offers fourteen different design disciplines through study programs at both graduate and post-graduate levels. They are structured to utilise the rich local traditions of arts and crafts in their teaching and research.

The FAA study pedagogy emphasises student skill development through studio-based and practical applications. It aims to strengthen the creation of visual objects that are designed to 
be aesthetically appealing, based on ornamented surfaces, and aligned with local traditional styles. Thereby, it aims to symbolically revive rich Egyptian craftsmanship. Overall, FAA teaching methods relied on three major resources: the Egyptian cultural taste, relating to material objects style and other preferences; reviving local traditional craftsmen's methods and applying skill development methods in the form of creation and styling; borrowing the Bauhaus traditional teaching methods of applied arts, craft skills, and technology (considering that pioneering FAA faculty staff members were graduated from German design institutions).

Teaching objectives aim mainly at developing students' abilities to think visually and demonstrate skills and resolutions physically. They also emphasise original creativity and the process of trial and error as characteristics of the arts and crafts tradition, and limited engaging in design as process informed by research.

The FAA represents the main hub for craft-oriented education in Egypt. It produces makers of new material objects and aligns modernity with the classical context through materialisation. This applied arts educational institution keeps maintaining its direction, neglecting the enormous changes in the context of design education occurring at all local, regional and international levels.

A wave of new design education institutions stablished since the early 2000s in the Gulf states, borrows design curriculum from European and American design schools and forces to teach it within a local context (Toutikian, 2010). This perspective presents a paradox in design education in the Arab world. Although educators are aware of the need to adapt design practices and education to culture, it is a challenging task to do so in such a highly politicised context. As the image of the East was formulated by the West (Said, 1979), using Western codes and standards to produce work that represents a non-Western culture can be another pigeonhole for local designers. This opens a discourse about individual perceptions of cultural identity and questions the notion of an "outside inside" approach that many Arab countries choose in order to pursue growth and development. In this context, Akkach (2014) articulated this relationship

In the Arab world, both the popular narrative and the official history set the intense encounter with Europe in the nineteenth century as the start of Western dominance and the marginalisation of local presence. They also set the postcolonial period as the beginning of the return; this was marked by the self-conscious search for cultural identity and the assertion of a national voice. (p. 69)

\section{Discussion and Refl ctions}

During the author's leadership role from 2012-2015 of the Faculty of Applied Sciences and Arts (FASA), German University in Cairo (GUC), the interdisciplinary design discourse was promoted to accommodate new dimensions in the relationships between humans, objects and social needs, which is articulated in the following vision statement: 
From its establishment FASA is supporting the GUC commitment to offer quality and a unique design educational institution in the region. Being in this position fostering FASA towards further interaction with the wider transformations that are happening in Egypt, as well as, in the region. Reflections of these interactions are promoting experimentation and professional practices in design education that are meant to empower our students to be professional, active, and creative members in their societies. (Saad, 2012)

This vision is based on the belief that the designer's role has shifted from a stylistic expert to that of a facilitator; overseeing selections of material and non-material solutions to empower individuals and communities to achieve well-being. In addition, it addresses FASA's path in order to strengthen and sustain its position as a leading design educational institution in the region, building on Cairo's rich location for design education and professional practices. Reflection of this context addressed through design students at FASA, choosing to develop design applications for their graduation projects that create new opportunities for design-oriented solutions targeting specific needs to improve and sustain the living conditions of various social groups. Some of the resulting projects fulfilled undergo continued development as internship projects in collaboration with social services done by design students from developing countries. This selected example Fig. 3 is one from many others, showing an attempt to empower the local designer to explore the significance of developing a sustainable design solution implementing available technology and skills, and targeted provides a creative solution to a local environmental problem (Saad, 2021).

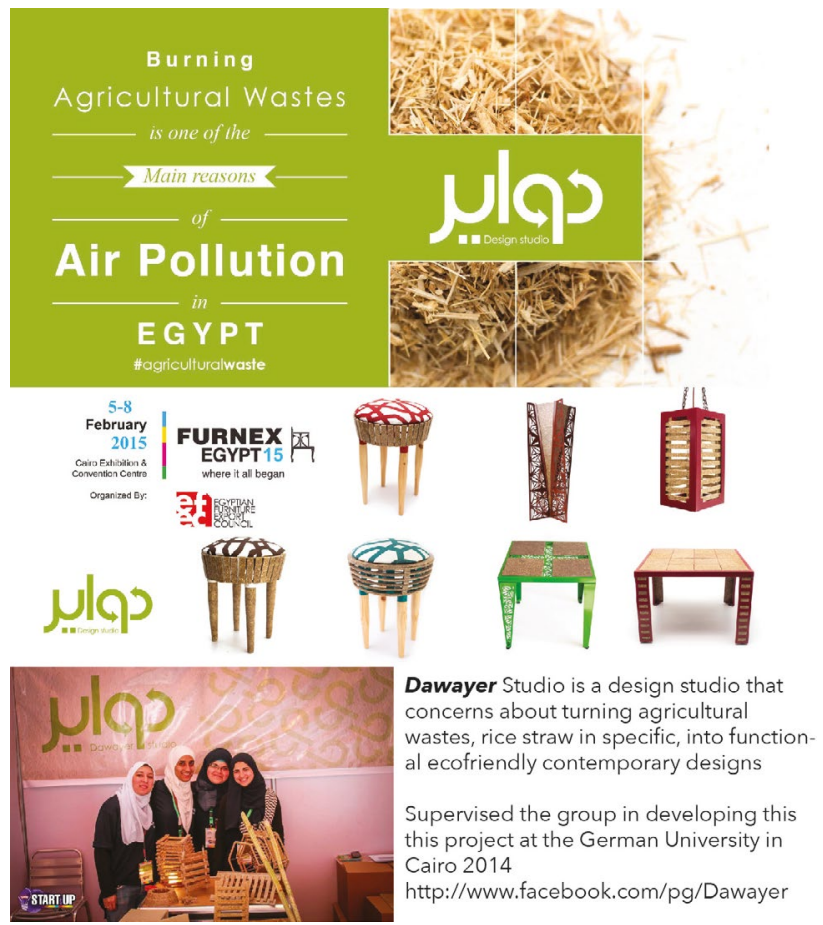

Fig. 3

Dawayer Studio, Design solution to environmental needs and social sustainability by Egyptian local designers (by Khadija Radwan, Habiba Shawkat, and Salma Sherif), German University in Cairo, 2014. 
Even with Egypt's deep roots in applied arts traditions and practices, graduates from local institutions are classified as "Applied Artists". As mentioned earlier, they are qualified to demonstrate skills relating to arts and making. Yet Egypt's current and future needs includes design services that provide creative thinking and innovative solutions. They must also be capable of fulfilling the growing demands of local industry and of becoming involved in new spheres related to the deterioration of social systems in the country. With ongoing degradation of the social service sector, including education, health and social security, the majority of Egyptians are living under the poverty threshold according to local and international criteria, which is a direct reflection of the challenges of development and modernisation policies to achieve their objectives. In fact, this situation reflecting ongoing negligence by inefficient, bureaucratic and corrupt public service agencies. This was a source of motivation for the 2011 public action against the previous regime which eventually caused conflict between opposing factions of Egyptian society that were fuelled and supported by regional and international powers. Furthermore, the sharp growing gap between social classes in Egypt is one that reflects a deeper socio-economic conflict.

There is a clear need for design services outside of the classical professions in the region. This reality creates new challenges. Also, directing design outside its traditional context following the modernists aim articulated by Persons "not to turn Design into a 'fine art' or tradition-based craft, but to blend the best elements of traditional craftsmanship, modern mass production, and fine art into a new way of producing material goods that made sense in the social context of contemporary life" (Galle, 2017, p. 327). Creating an opportunities for improving living conditions that cannot find satisfactory solutions in the institutionalised fields of public or private action. These are clearer objectives for social interaction design discourse, where "the local is our interface with the whole world" (Manzini, 2015, p. 3). Where design and the designer roles offering according to Manzini "three human gifts: critical sense (the ability to look at the state of things and recognize what cannot, or should not be, acceptable), creativity (the ability to imagine something that does not yet exist), and practical sense (the ability to recognize feasible ways of getting things to happen)" (Manzini, 2015, p. 31). In this context, design will engage with society and create opportunity-based creative scenarios to solve society's complex problems. This means that designers must consider the collaborative and interdisciplinary nature of knowledge in learning and teaching practices for future designers.

\section{Qassim Saad}

An Iraqi industrial designer living in exile since 1991, holding BA, MA and Ph.D. in Industrial Design. He taught Design and assigned for academic leadership roles since 1984 in Iraq, Jordan, New Zealand, Egypt, Germany, and recently here in Australia. Saad research embraces creative practice outputs and traditional scholarly publications related to design and social innovation at the marginal countries. 
Akkach, S. (2014). Modernity and Design in the Arab World. Professional Identity and Social Responsibility. In K. Eleni, \& F. Toni (Eds.), Design in the Borderlands (pp. 61-75). Routledge.

Al-Fakharani, A. (2016). Wood. Tales of a Noble Material. In M. el-Batraoui (Ed.), The Traditional Crafts of Egypt. The American University in Cairo Press.

Al-Musawi, M. (2006). Reading Iraq. Culture and Power in Conflict. I. B. Tauris.

Baudrillard, J. (2002). The System of Objects. Verso.

Cannadine, D. (2001). Orientalism. How the British Saw Their Empire. Oxford University Press.

Chadirji, R. (1995). Dialogue on the Structure of Art and Architecture. Raid El-Rayyes Books Ltd.
Faroqhi, S. (2012). Artisans of Empire. Crafts and Craftspeople under the Ottomans. I. B. Tauris.

Fry, T. (2011). Design as Politics. Berg.

Fry, T., \& Eleni, K. (2014). An Introduction. In K. Eleni, \& F. Toni (Eds.), Design in the Borderlands. Routledge.

Galle, P. (2017). Self-Knowledge by Proxy: Parsons on Philosophy of Design and the Modernist Vision. she ji, The Journal of Design, Economics, and Innovation, 2(4), 322-341.

Hourani, A. (2005). A History of the Arab People. Faber and Faber.

Lee, R.D. (1997). Overcoming Tradition and Modernity. The Search for Islamic Authenticity. Westview Press.

Mackintosh, S.T. (2019). Arabs. A 3000-year history of peoples, tribes, and empires. Yale University Press.
Manzini, E. (2015). Design, When Everybody Designs. An Introduction to Design for Social Innovation. MIT Press.

Mignolo, W. (2011). The Darker Side of Western Modernity. Global Future, Decolonial Options. Duck University Press.

Radhakrishnan, R. (2012). A Said Dictionary. John Wiley \& Sons.

Saad, Q. (2012). Framework for the Faculty of Applied Sciences and Art [Unpublished official document].

Saad, Q. (2013). Framework for revisioning design in Iraq [Unpublished doctoral dissertation]. The School of Architecture and Design, Royal Melbourne Institute of Technology (RMIT University).
Saad, Q. (2020). The intellectual transformation of modern design discourses in the Eastern Mediterranean Region (EMR). In R. Leitão, L. Noel, \& L. Murphy (Eds.), Pivot 2020: Designing a World of Many Centers - DRS Pluriversal Design SIG Conference, 4 June, held online. https:// doi.org/10.21606/pluriversal.2020.014

Saad, Q. (2021). Interdisciplinary Design Approach-Led Multicultural Perspective Teaching Practice. In A. Bosco, \& S. Gasparotto (Eds.), Updating Values. Perspectives on Design Education (pp. 182185). Quodlibet.

Said, E.W. (1979). Orientalism. Vintage Books.

Toutikian, D. (2010). Design Education in the Middle East. http://issuu.com/ doreentoutikian/docs/masterthesis 